\title{
Hybrid Rice Seed Treatment with Pesticides Improves Its Physiological Quality and Performance
}

\author{
Andréia da Silva Almeida1 ${ }^{*}$, César Iván Suárez Castellanos ${ }^{1}$, Cristiane Deuner ${ }^{1}$, \\ Adilson Jauer ${ }^{2}$, Thais Ongaratto de Camargo' ${ }^{1}$, Cristian Troyjack ${ }^{1}$, \\ Geri Eduardo Meneghello', Francisco Amaral Villela', \\ Paulo Dejalma Zimmer ${ }^{1}$, Lilian Madruga de Tunes ${ }^{1}$ \\ ${ }^{1}$ PPG em Ciência e Tecnologia de Sementes, Universidade Federal de Pelotas, Pelotas, Brazil \\ ${ }^{2}$ Syngenta Crop Protection, Pelotas, Brazil \\ Email: ${ }^{*}$ andreiasalmeida@yahoo.com.br
}

Received 5 August 2015; accepted 22 September 2015; published 25 September 2015

Copyright (C) 2015 by authors and Scientific Research Publishing Inc. This work is licensed under the Creative Commons Attribution International License (CC BY). http://creativecommons.org/licenses/by/4.0/

(c) (i) Open Access

\section{Abstract}

Pathogens in the soil or transmitted by seeds can reduce the stand of plants, affecting the yield of the crop. Furthermore, in the case of rice, the low temperature is a limiting factor in culture. The treatment of seeds with insecticides is an alternative to reduce the damage caused by pests incidents during the early stages of plant development and in some cases, may assist in the germination of seeds exposed to low temperatures. In this sense, the objective of this study was to evaluate the influence of seed treatment with insecticides in the physiological quality and yield of hybrid rice seeds, cv. Inov CL. For this, three experiments were conducted with treated seeds in different doses of thiamethoxam + lambda-cyhalothrin and fipronil totaling seven treatments, including the control (no product). In the first experiment, it was determined seed germination to $10^{\circ} \mathrm{C}, 13^{\circ} \mathrm{C}$, $16^{\circ} \mathrm{C}, 20^{\circ} \mathrm{C}$ and $25^{\circ} \mathrm{C}$. In the second experiment, it was assessed seed vigor through accelerated aging, cold test and emergency field. The third experiment was carried out into the field to observe the number of panicles $\mathrm{m}^{-2}$ and crop yield. It is concluded that treatment of hybrid rice seeds, cv. Inov CL with thiamethoxam + lambda-cyhalothrin and fipronil increases the germination percentage of seed and early seedling performance. Treatment of hybrid rice seeds, cv. Inov CL with thiamethoxam + lambda-cyhalothrin provides greater germination and early seedling performance compared to treatment with fipronil. Treatment of hybrid rice seeds, cv. Inov CL with thiamethoxam + lambda-cyhalothrin in dosages of $500 \mathrm{~mL} 100 \mathrm{~kg}^{-1}$ of seeds or $500 \mathrm{~mL} 45 \mathrm{~kg}^{-1} \mathrm{of} \mathrm{seeds}^{-10}$ increases grain yield.

\footnotetext{
${ }^{*}$ Corresponding author.

How to cite this paper: Almeida, A.S., Castellanos, C.I.S., Deuner, C., Jauer, A., de Camargo, T.O., Troyjack, C., Meneghello, G.E., Villela, F.A., Zimmer, P.D. and de Tunes, L.M. (2015) Hybrid Rice Seed Treatment with Pesticides Improves Its Physiological Quality and Performance. American Journal of Plant Sciences, 6, 2405-2411.

http://dx.doi.org/10.4236/ajps.2015.614243
} 


\section{Keywords}

\section{Oryza sativa L., Vigor, Yield Potential}

\section{Introduction}

Rice (Oryza sativa L.) is a staple food of the population [1], and the state of Rio Grande do Sul is the main producer of cereal in Brazil (approximately 69\%). Its average productivity, in the last harvest, was $7716 \mathrm{~kg} \cdot \mathrm{ha}^{-1}$ and its production was 8.64 million of tons. Rice is the third most produced grain in the country, overcomes only to corn and soybean [2].

The search for higher yields reconciled to the seed quality is a challenge to the growing food needs of the planet. Pathogens in the soil or transmitted by seeds can reduce the stand of plants, causing crop failures, because they can feed of seeds, roots and shoots of plants [3] and thus affect crop yield.

Seed treatment-application processes and substances allowing all cultures express their genetic potential [4] with insecticides, which is a widely adopted practice, giving the plant protection conditions and contributing to the achievement of the desired booth [3]. The treatment of seeds with insecticides is considered a cheap and viable alternative to reducing the damage caused by soil and shoot pests incidents during the early stages of plant development [5]. Within this context, it is becoming common to use insecticides that have physiological activities in plants, with fito-tonic effect, favoring vigorous growth and better use of their productive potential [6]. Furthermore, according Menten [7], treatment of seeds with insecticides is a practice that is possible to reduce the number of applications of insecticide after emergence of the crop in most cases.

Another limiting factor for rice crop in the Rio Grande do Sul state is the low temperatures in the period of sowing and germination. The optimum temperature for development of the rice is between $25^{\circ} \mathrm{C}$ and $30^{\circ} \mathrm{C}$ [8], below that may occur cold stress, which is considered one of the most important abiotic stresses for rice [9].

The insecticide thiamethoxam has the ability to assist in the initial performance of the seedlings, which are verified in different cultures [10]-[13] and seed yield [14]. The treatment of rice seeds, cv. BR IRGA 428, BR IRGA 424 and Puita INTA CL, with thiamethoxam + lambda-cyhalothrin provided an increase of germination, being the treatment response more pronounced when the test was performed at low temperatures $\left(10^{\circ} \mathrm{C}\right.$ and $\left.13^{\circ} \mathrm{C}\right)$ [15]. The treatment of soybean seeds with the insecticides thiamethoxam, fipronil and imidacloprid did not affect negatively the physiological seed quality and initial development of plants [16].

The state of Rio Grande do Sul has been highlighted by the use of seed treatment, especially with fungicides and insecticides [17]. Furthermore, the adoption of hybrid rice, which has yield 20\% - 25\% higher than the best varieties [18], has increased in the state in recent years, with higher cultivation to 70,000 ha in 2014 [19]. In this sense, the objective of this study was to evaluate the influence of seed treatment with insecticide thiamethoxam + lambda-cyhalothrin and fipronil in the physiological quality and yield of hybrid rice seeds, cv. Inov CL.

\section{Material and Methods}

Hybrid rice seeds, cv. Inov CL, treated with two commercial products called Crusier Opti ${ }^{\circledR}$ (thiamethoxam + lambda-cyhalothrin) and Standak ${ }^{\circledR}$ (fipronil) in different doses were used, as shown in Table 1 and considering that the recommended amount of seed for this cultivar is $45 \mathrm{~kg} \cdot \mathrm{ha}^{-1}$. Seed treatment was done using a spray volume of $1.5 \mathrm{~L} 100 \mathrm{~kg}^{-1}$ of seed, varying the quantities of products and water as each treatment. The spray was deposited on the bottom of a plastic bag with the help of a micropipette and then be distributed inside it. Later, the seeds were added to the bag and shaking manually until the coating with the product stay smooth. Finally, the seeds were removed and spread on plastic trays to dry. Once dried, they were packaged in paper bags and stored under controlled conditions of relative humidity $(60 \%)$ and temperature $\left(16^{\circ} \mathrm{C}\right)$.

The effect of seed treatment with thiamethoxam + Lambda-cyhalothrin and fipronil was evaluated by three experiments. The first experiment evaluated the germination of seeds under various temperatures. For this 200 seeds per repetition distributed in four rolls of paper for germination with 50 seeds each were used. The paper was moistened with distilled water at a ratio of 2.5 times its dry weight and the seeds were germinated at $10^{\circ} \mathrm{C}$, $13^{\circ} \mathrm{C}, 16^{\circ} \mathrm{C}, 20^{\circ} \mathrm{C}$ and $25^{\circ} \mathrm{C}$. Counts were performed at 5 and 14 days after sowing, according to the RAS [20].

The second experiment was to determine seed vigor by the following tests: 
Table 1. Products and doses used in the treatment of hybrid rice seeds, cv. Inov CL.

\begin{tabular}{|c|c|c|c|c|}
\hline Treatment & Product & Active ingredient & Concentration & Dose \\
\hline TR1 & Control & - & - & - \\
\hline TR2 & Crusier Opti & $\begin{array}{l}\text { Thiamethoxam } \\
\text { Lambda-cyhalothrin }\end{array}$ & $\begin{array}{l}210 \mathrm{~g} \cdot \mathrm{L}^{-1} \\
37.5 \mathrm{~g} \cdot \mathrm{L}^{-1}\end{array}$ & 400 (mL $100 \mathrm{~kg}^{-1}$ of seeds) \\
\hline TR3 & Crusier Opti & $\begin{array}{l}\text { Thiamethoxam } \\
\text { Lambda-cyhalothrin }\end{array}$ & $\begin{array}{l}210 \mathrm{~g} \cdot \mathrm{L}^{-1} \\
37.5 \mathrm{~g} \cdot \mathrm{L}^{-1}\end{array}$ & $500\left(\mathrm{~mL} 100 \mathrm{~kg}^{-1}\right.$ of seeds) \\
\hline TR4 & Standak & Fipronil & $250 \mathrm{~g} \cdot \mathrm{L}^{-1}$ & $120\left(\mathrm{~mL} 100 \mathrm{~kg}^{-1}\right.$ of seeds $)$ \\
\hline TR5 & Crusier Opti & $\begin{array}{l}\text { Thiamethoxam } \\
\text { Lambda-cyhalothrin }\end{array}$ & $\begin{array}{l}210 \mathrm{~g} \cdot \mathrm{L}^{-1} \\
37.5 \mathrm{~g} \cdot \mathrm{L}^{-1}\end{array}$ & 400 (mL $45 \mathrm{~kg}^{-1}$ of seeds) \\
\hline TR6 & Crusier Opti & $\begin{array}{l}\text { Thiamethoxam } \\
\text { Lambda-cyhalothrin }\end{array}$ & $\begin{array}{l}210 \mathrm{~g} \cdot \mathrm{L}^{-1} \\
37.5 \mathrm{~g} \cdot \mathrm{L}^{-1}\end{array}$ & 500 (mL $45 \mathrm{~kg}^{-1}$ of seeds) \\
\hline TR7 & Standak & Fironil & $250 \mathrm{~g} \cdot \mathrm{L}^{-1}$ & 120 (mL $45 \mathrm{~kg}^{-1}$ of seeds) \\
\hline
\end{tabular}

Accelerated aging (EA\%): conducted in plastic boxes type gerbox which seeds were deposited in a single layer on a metal screen suspended within the box containing $40 \mathrm{~mL}$ of distilled water. The capped boxes were transferred to BOD (Biochemical Oxygen Demand) chamber at $42^{\circ} \mathrm{C}$ for 96 hours. After this period, each replicate with 200 seeds, distributed in four rolls 50 seeds each were placed to germinate in a germination chamber at $25^{\circ} \mathrm{C}$. The count was performed five days after sowing, computing the normal seedlings. Normal seedlings had a well-formed root system and perfect coleoptile with a well-developed leaf (plumule) indoors or emerged this.

Cold test (TF\%): accomplished with 200 seeds per repetition distributed in four rolls of 50 seeds each. The rolls containing seeds were packed in plastic bags, which were closed and taken to a BOD chamber at $10^{\circ} \mathrm{C}$ and kept in this condition for 7 days. After this period, the rolls were removed from the bags and placed in a germination chamber at $25^{\circ} \mathrm{C}$. The count of normal seedlings was performed after five days.

Emergency field (EC\%): conducted using 50 seeds per repetition, which were planted in beds containing soil. The evaluation was performed in a single day, 21 days after sowing.

The third experiment was conducted to observe the crop yield. For this, were conducted an experiment in field, where each experimental unit consisted of a plot of $11.05 \mathrm{~m}^{2}$. In each plot were sown 13 lines with a spacing of $17 \mathrm{~cm}$ and length of $5 \mathrm{~m}$. The seeding rate was $45 \mathrm{~kg} \cdot \mathrm{ha}^{-1}$ and the base fertilization was performed applying 300 $\mathrm{kg} \cdot \mathrm{ha}^{-1}$ of 2-15-30. The other cultivations followed the technical recommendations for culture. At the end of the cycle it was determined the number of panicles per square meter and the grain weight corrected to $13 \%$ moisture.

The first experiment (germination) was conducted under completely randomized design in $5 \times 7$ factorial design (five temperatures and seven seed treatments). The second experiment (vigor) was conducted under completely randomized design with four replications and the third experiment (yield) was conducted in a randomized block design with five replications.

Comparing mean of all experiments was performed by Tukey test at $5 \%$ probability, and in the case of the first experiment, there was polynomial regression with $\mathrm{p}<0.05$.

\section{Results and Discussion}

As the result of analysis of variance, seed germination responded to the interaction between the two factors, temperature and seed treatment. It can be seen that the seeds treated with thiamethoxam + lambda-cyhalothrin, regardless of the dosage used, showed statistically higher percentage of germination than seeds of other treatments in the five temperatures studied (Table 2). Already in treatments where fipronil was used, the percentage of seed germination was statistically equal to the control at $10^{\circ} \mathrm{C}$ and higher than this in other temperatures. In a study with bean seeds treated with thiamethoxam, it was found that the product provided increases in germination [21]. Evaluating the treatment of bean seeds with fungicides and insecticides, the researchers observed that in the treatment with fipronil there was a higher percentage of germination [22].

The optimum temperature range for rice production is between $25^{\circ} \mathrm{C}$ and $30^{\circ} \mathrm{C}$, while temperatures below $20^{\circ} \mathrm{C}$ are generally detrimental [8], especially in germination and early stages of seedling development and reproductive [23]. According to Mertz et al. [9], cold affects negatively the seed germination and the initial performance of rice seedlings. It can be observed that the treatments TR2 (thiamethoxam + Lambda-cyhalothrin: $400 \mathrm{~mL}$ for $100 \mathrm{~kg}^{-1}$ of seeds); TR3 (thiamethoxam + Lambda-cyhalothrin: $500 \mathrm{~mL}$ for $100 \mathrm{~kg}^{-1}$ of seeds); TR5 
(thiamethoxam + lambda-cyhalothrin: $400 \mathrm{~mL} 45 \mathrm{~kg}^{-1}$ of seeds) and TR6 (thiamethoxam + lambda-cyhalothrin: $500 \mathrm{~mL} 45 \mathrm{~kg}^{-1}$ of seeds), germinated above $80 \%$ at $16^{\circ} \mathrm{C}$, indicating an improvement in germination rice seeds with these treatments when subjected to low temperatures (Table 2).

Analyzing the behavior of the different treatments versus temperature (Figure 1), it is observed that the germination of the seeds increases as the temperature increases, regardless of treatment. However, in treatments that used thiamethoxam + lambda-cyhalothrin, the seeds showed a higher percentage of germination than the other treatments. In addition, it can be seen that the $10^{\circ} \mathrm{C}$, seeds of treatments with fipronil and the control showed a statistically equal germination, but with increasing of temperature the seeds treated with fipronil showed an

Table 2. Percentage of germination of hybrid rice seed, cv. Inov CL, treated with various products and in different dosages, subject to various germination temperatures.

\begin{tabular}{|c|c|c|c|c|c|c|c|}
\hline \multirow{2}{*}{ Treatment } & \multicolumn{5}{|c|}{ Temperature ${ }^{\circ} \mathrm{C}$} & \multirow{2}{*}{ Mean } & \multirow{2}{*}{ CV (\%) } \\
\hline & 10 & 13 & 16 & 20 & 25 & & \\
\hline TR1 & $40 \mathrm{~b}$ & $46 \mathrm{c}$ & $56 \mathrm{c}$ & $61 \mathrm{c}$ & $66 \mathrm{c}$ & 54 & \multirow{8}{*}{2,42} \\
\hline TR2 & 63 a & $72 \mathrm{a}$ & 82 a & $88 \mathrm{a}$ & 93 a & 80 & \\
\hline TR3 & $64 \mathrm{a}$ & $74 \mathrm{a}$ & $84 \mathrm{a}$ & 89 a & $91 \mathrm{a}$ & 80 & \\
\hline TR4 & $41 \mathrm{~b}$ & $56 \mathrm{~b}$ & $64 \mathrm{~b}$ & $70 \mathrm{~b}$ & $80 \mathrm{~b}$ & 62 & \\
\hline TR5 & $62 \mathrm{a}$ & $72 \mathrm{a}$ & $82 \mathrm{a}$ & $91 \mathrm{a}$ & $94 \mathrm{a}$ & 80 & \\
\hline TR6 & 63 a & $72 \mathrm{a}$ & $84 \mathrm{a}$ & $91 \mathrm{a}$ & 93 a & 81 & \\
\hline TR7 & $38 \mathrm{~b}$ & $56 \mathrm{~b}$ & $67 \mathrm{~b}$ & $70 \mathrm{~b}$ & $80 \mathrm{~b}$ & 62 & \\
\hline Mean & 53 & 64 & 74 & 80 & 85 & - & \\
\hline
\end{tabular}

Means followed by the same letter in the column do not differ by Tukey test with $\mathrm{p}<0.05$.

TR1: Control; TR2: thiamethoxam + Lambda-cyhalothrin (400 mL for $100 \mathrm{~kg}^{-1}$ of seeds); TR3: thiamethoxam + Lambda-cyhalothrin (500 mL for $100 \mathrm{~kg}^{-1}$ of seeds); TR4: fipronil (120 mL for $100 \mathrm{~kg}^{-1}$ of seeds); TR5: thiamethoxam + Lambda-cyhalothrin (400 mL $45 \mathrm{~kg}^{-1}$ of seeds); TR6: thiamethoxam + Lambda-cyhalothrin (500 mL $45 \mathrm{~kg}^{-1}$ of seeds); TR7: fipronil (120 mL $45 \mathrm{~kg}^{-1}$ of seeds).

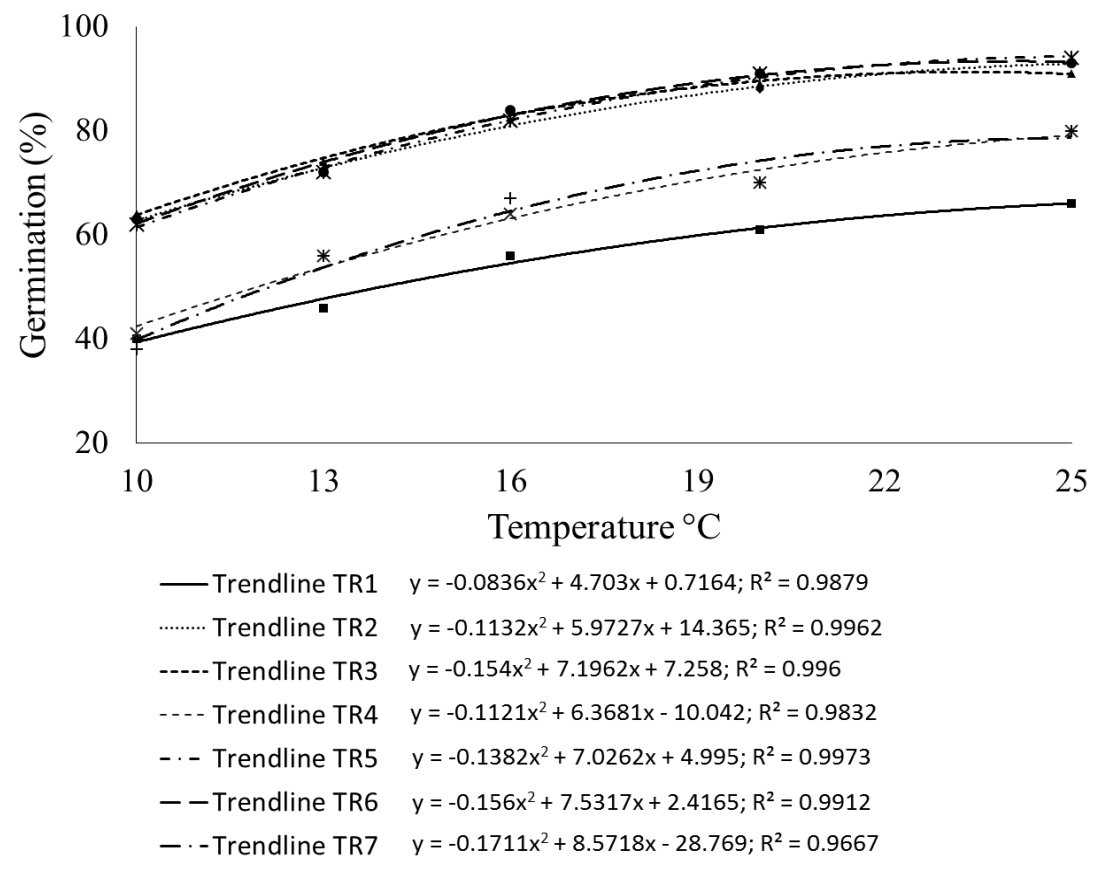

TR1: Control; TR2: thiamethoxam + Lambda-cyhalothrin (400 mL for $100 \mathrm{~kg}^{-1}$ of seeds); TR3: thiamethoxam + Lambda-cyhalothrin (500 mL for $100 \mathrm{~kg}^{-1}$ of seeds); TR4: fipronil (120 mL for $100 \mathrm{~kg}^{-1} \mathrm{of}^{-}$ seeds); TR5: thiamethoxam + Lambda-cyhalothrin (400 mL $45 \mathrm{~kg}^{-1}$ of seeds); TR6: thiamethoxam + Lambda-cyhalothrin (500 mL $45 \mathrm{~kg}^{-1}$ of seeds); TR7: fipronil (120 mL $45 \mathrm{~kg}^{-1}$ of seeds).

Figure 1. Effect of different temperatures on the percentage of germination of hybrid rice seeds, cv. Inov CL treated with different products and in different dosages. 
increase higher in germination than control. It also observed that seed treatment with thiamethoxam + lambda-cyhalothrin and fipronil increased seed germination.

Rice seeds treated with thiamethoxam, even when exposed to low temperatures $\left(10^{\circ} \mathrm{C}\right.$ and $\left.13^{\circ} \mathrm{C}\right)$, had negative effect of cold mitigated, providing increases in the germination of normal seedlings [15].

Analyzing the vigor of seeds after treatment, through accelerated aging, cold and emergency field tests, it was observed that the treatments containing thiamethoxam + lambda-cyhalothrin showed a statistically superior germination, followed by treatment with fipronil and finally the control (Table 3). The thiamethoxam insecticide may have a beneficial effect on seedling vigor [24], this is because the thiamethoxam has properties of bioactivator [25]. According to Castro and Pereira [26], an bio-activator is an organic substance that interferes with gene expression, DNA transcription, production of membrane proteins, metabolic enzymes and mineral nutrition. Therefore, it can promote positive responses in the development and plant productivity and increase the synthesis of amino acid precursors, new proteins and endogenous synthesis of plant hormones, with significant increases in production [25].

Dan et al. [27] studying the physiological performance of soybean seeds treated with insecticides, observed that the treatment with the insecticide fipronil and thiamethoxam not adversely affected the germination and vigor of the seeds. Similarly, Grisi et al. [28] evaluating the effect of treatment of sunflower seeds with fipronil and thiamethoxam, showed no change in the vigor and the emergence. Vanin et al. [29] concluded that the treatments with fipronil, thiamethoxam, thiamethoxam + thiodicarb and imidacloprid + thiodicarb, are suitable for treating sorghum seeds. Further, according to Almeida et al. [10], treatment with thiamethoxam favors positively the physiological quality of rice seeds, cv. El Paso, BR IRGA 410, IRGA 424 and BR Olimar.

Cataneo [30] noted that the thiamethoxam increases seed germination, photosynthesis rate, the accumulation of dry matter and root depth. Also, Castro [31] reported that this molecule acts in the expression of genes to synthesize and activate enzymes related to plant growth, increasing the production of amino acids precursors of plant hormone. This fact was confirmed by Tavares et al. [32], who reported that thiamethoxam is a molecule moves through the cells enabling many physiological reactions, e.g., expression of functional proteins related to plant defense mechanisms against stress factors.

Regarding the results of the productive potential of the seeds (Table 3), it is observed that the grain yield of treatments TR3 (500 mL of thiamethoxam + lambda-cyhalothrin $100 \mathrm{~kg}^{-1}$ of seeds) and TR6 (500 mL of thiamethoxam + lambda-cyhalothrin $45 \mathrm{~kg}^{-1}$ of seeds) was statistically superior to the other treatments, while the control was statistically inferior to all treatments. Also, it can be seen that there is a difference of $2383.2 \mathrm{~kg} \cdot \mathrm{ha}^{-1}$ between the TR3 treatment and the control. Nevertheless, in the number of panicles $\mathrm{m}^{-2}$, the treatment TR3 was statistically superior and the control was statistically lower to the other treatments.

Evaluating the treatment of oats seeds, cv. URS Taura with thiamethoxam, it was concluded that pesticide stimulates the physiological performance and the yield of seeds produced [14]. In rice, Clavijo [33] found increase of the germination, vigor and productivity of seeds treated with thiamethoxam.

Table 3. Accelerated aging, cold test, emergency field and productive potential of hybrid rice seeds, cv. Inov CL treated with different products and in different dosages.

\begin{tabular}{cccccc}
\hline Treatment & Accelerated aging (\%) & Cold test (\%) & Emergency field (\%) $^{\text {Yield kg.ha }}{ }^{-1}$ & Panicles m $^{-2}$ \\
\hline TR1 & $62 \mathrm{c}$ & $58 \mathrm{c}$ & $61 \mathrm{c}$ & $7412.3 \mathrm{~b}$ & $484 \mathrm{~d}$ \\
TR2 & $90 \mathrm{a}$ & $91 \mathrm{a}$ & $90 \mathrm{a}$ & $8772.8 \mathrm{ab}$ & $744 \mathrm{abc}$ \\
TR3 & $87 \mathrm{a}$ & $89 \mathrm{a}$ & $90 \mathrm{a}$ & $9795.5 \mathrm{a}$ & $764 \mathrm{a}$ \\
TR4 & $71 \mathrm{~b}$ & $69 \mathrm{~b}$ & $68 \mathrm{~b}$ & $8711.8 \mathrm{ab}$ & $676 \mathrm{c}$ \\
TR5 & $89 \mathrm{a}$ & $91 \mathrm{a}$ & $91 \mathrm{a}$ & $8842.5 \mathrm{ab}$ & $732 \mathrm{abc}$ \\
TR6 & $90 \mathrm{a}$ & $91 \mathrm{a}$ & $91 \mathrm{a}$ & $9441.8 \mathrm{a}$ & $760 \mathrm{ab}$ \\
TR7 & $71 \mathrm{~b}$ & $67 \mathrm{~b}$ & $67 \mathrm{~b}$ & $8761.8 \mathrm{ab}$ & $684 \mathrm{bc}$ \\
Mean & 80 & 79 & 80 & 8819.8 & 692 \\
CV (\%) & 3,1 & 2,0 & 1,6 & 7,5 & 4,9 \\
\hline
\end{tabular}

Means followed by the same letter in the column do not differ by Tukey test with $\mathrm{p}<0.05$.

TR1: Control; TR2: thiamethoxam + Lambda-cyhalothrin (400 mL for $100 \mathrm{~kg}^{-1}$ of seeds); TR3: thiamethoxam + Lambda-cyhalothrin (500 mL for $100 \mathrm{~kg}^{-1}$ of seeds); TR4: fipronil (120 mL for $100 \mathrm{~kg}^{-1}$ of seeds); TR5: thiamethoxam + Lambda-cyhalothrin (400 mL $45 \mathrm{~kg}^{-1}$ of seeds); TR6: thiamethoxam + Lambda-cyhalothrin (500 mL $45 \mathrm{~kg}^{-1}$ of seeds); TR7: fipronil (120 mL $45 \mathrm{~kg}^{-1}$ of seeds). 
In general, it can be seen that both products used improved the germination, vigor and productive potential, measured by yield and number of panicles $\mathrm{m}^{-2}$, of the seeds treated compared to untreated.

\section{Conclusions}

Treatment of hybrid rice seeds, cv. Inov CL with thiamethoxam + lambda-cyhalothrin and fipronil increases the percentage of seed germination and early seedling performance.

Treatment of hybrid rice seeds, cv. Inov CL with thiamethoxam + lambda-cyhalothrin provides greater germination and early seedling performance compared to treatment with fipronil.

Treatment of hybrid rice seeds, cv. Inov CL with thiamethoxam + lambda-cyhalothrin in dosages of $500 \mathrm{~mL}$ $100 \mathrm{~kg}^{-1}$ seeds or $500 \mathrm{~mL} 45 \mathrm{~kg}^{-1}$ of seeds increases grain yield.

\section{References}

[1] Jung, K., An, G. and Ronald, P.C. (2008) Towards a Better Bowl of Rice: Assigning Function to Tens of Thousands of Rice Genes. Nature Reviews Genetics, 9, 91-101. http://dx.doi.org/10.1038/nrm2343

[2] Conab-Companhia nacional de abastecimento (2015) Acompanhamento da safra brasileira de grãos. Décimo levantamento, Safra 2014/2015. http://www.conab.gov.br/OlalaCMS/uploads/arquivos/15_07_09_08_59_32_boletim_graos_julho_2015.pdf

[3] Baudet, L. and Peske, F. (2007) Aumentando o desempenho das sementes. Seed News, 9, 22-24. http://www.seednews.inf.br/portugues/seed115/print_artigo115.html

[4] Menten, J.O. and Moraes, M.H.D. (2010) Tratamento de sementes: histórico, tipos, características e benefício. Informativo Abrates, 20, 52-53.

[5] Martins, G.M., Toscano, L.C., Tomquelski, G.V. and Maruyama, W.I. (2009) Inseticidas químicos e microbianos no controle da lagarta-do-cartucho na fase inicial da cultura do milho. Revista Caatinga, 22, 70-174.

[6] Castro, G.S.A., Bogiani, J.C., Silva, M.G., Gazola, E. and Rosolem, C.A. (2008) Tratamento de sementes de soja com inseticidas e um bioestimulante. Pesquisa Agropecuária Brasileira, 43, 1311-1318. http://dx.doi.org/10.1590/S0100-204X2008001000008

[7] Menten, O.J. (2005) Tratamento de sementes no Brasil. Seed News, 1, 30-32.

[8] Yoshida, S. (1981) Fundamentals of rice cropscience. International Rice Research Institute, Los Bãnos.

[9] Mertz, L.M., Henning, F.A., Soares, R.C., Baldiga, R.F., Peske, F.B. and Moraes, D.M. (2009) Alterações fisiológicas em sementes de arroz expostas ao frio na fase de germinação. Revista Brasileira de Sementes, 31, Nota Científica. http://dx.doi.org/10.1590/s0101-31222009000200031

[10] Almeida, A.S., Carvalho, I., Deuner, C., Tillmann, M.A.A. and Villela, F.A. (2011) Bioativador no desempenho fisiológico de sementes de arroz. Revista Brasileira de Sementes, 33, 501-510. http://dx.doi.org/10.1590/S0101-31222011000300013

[11] Almeida, A.S., Villela, F.A., Meneghello, G.E., Lauxen, L.R. and Deuner, C. (2012) Desempenho fisiológico de sementes de aveia-preta tratadas com thiamethoxam. Semina: Ciências Agrárias, 33, 1619-1628. http://dx.doi.org/10.5433/1679-0359.2012v33n5p1619

[12] Denardi, N.D. (2008) Ação do tiametoxam sobre a fixação biológica do nitrogênio e na promoção de ativadores de crescimento vegetal. In: Gazzoni, D.L., Ed., Tiametoxam: Uma Revolução na Agricultura Brasileira, Vozes, São Paulo, 74-116.

[13] Tavares, S., Castro, P.R.C., Ribeiro, R.V. and Aramaki, P.H. (2008) Avaliação dos efeitos fisiológicos de thiametoxam no tratamento de sementes de soja. In: Gazzoni, D.L., Ed., Thiametoxam: Uma Revolução na Agricultura. Vozes, Petrópolis, 193-204.

[14] de Mendonça, A.O., Ritter, R., das Neves, E.H., Gehling, V.M. and da Silva Pedroso, C.E. (2014) Tratamento de sementes de aveia branca com tiametoxam: Efeito na qualidade fisiológica e no rendimento. Enciclopédia Biosfera, 10, 1779-1788.

[15] Almeida, A.S., de Oliveira, S., Jauer, A., Meneghello, G.E. and Barreto, B. (2014) Influência do tratamento de sementes de arroz com bioativador sob estresse de baixa temperatura. Enciclopédia Biosfera, 10, 2020-2028.

[16] Dan, L.G.M., Goulart, M.M.P., Dan, H.A., Silva, A.G., Barroso, A.L.L., Braccini, A.L. and Menezes, J.F.S. (2012) Desempenho de sementes de girassol tratadas com inseticidas sob diferentes períodos de armazenamento. Revista Trópica-Ciências Agrárias e Biológicas, 6, 30-37.

[17] Franco, D.F., Junior, A.M.M., Costa, C.J. and Silva, M.G. (2013) Colheita, Secagem, Beneficiamento e Tratamento de Sementes de Arroz Irrigado. Embrapa Clima Temperado, Pelotas. 
[18] Rather, A.G., Zargar, M.A. and Sheikh, F.A. (2001) Genetic Divergence in Rice (Oryza sativa L.) under Temperate Conditions. Indian Journal Agricultural Science, 71, 344-345.

[19] Peske, S.T. (2015) Arroz híbrido no Brasil. Seed News, 3, 20-23.

[20] Coordenação de Laboratório Vegetal (2009) Regras para Análise de Sementes. Ministério da Agricultura e Reforma Agrária, Secretaria Nacional de Defesa Agropecuária, Departamento Nacional de Produção Vegetal, Coordenação de Laboratório Vegetal, Brasília.

[21] Carvalho, L.S.M. de J. de, Rodrigues, H.C.S., Meneghello, G.E., Almeida, A.S. and Navroski, R. (2014) Desempenho fisiológico de sementes de feijão tratadas com produto bioativador. Enciclopédia Biosfera, 10, 1163-1172.

[22] Barros, R.G., Barrigossi, J.A.F. and Costa, J.L.S. (2005) Efeito do armazenamento na compatibilidade de fungicidas e inseticidas, associados ou não a um polímero no tratamento de sementes de feijão. Bragantia, 64, 459-465. http://dx.doi.org/10.1590/S0006-87052005000300016

[23] Cruz, R.P. and Milach, S.C.K. (2000) Melhoramento genético para tolerância ao frio em arroz irrigado. Ciência Rural, 30, 909-917. http://dx.doi.org/10.1590/S0103-84782000000500031

[24] Horii, A., McCue, P. and Shetty, K. (2007) Enhancement of Seed Vigour Following Insecticide and Phenolic Elicitor Treatment. Bioresource Technology, 98, 623-632. http://dx.doi.org/10.1016/j.biortech.2006.02.028

[25] Carvalho, N.L., Perlin, R.S. and Costa, E.C. (2011) Tiametoxam em tratamento de sementes. Revista Eletrônica do PPGEAmb-CCR/UFSM, 2, 158-175.

[26] Castro, P.R.C. and Pereira, M.A. (2008) Bioativadores na agricultura. In: Gazzoni, D.L., Ed., Tiametoxam: Uma Revolução na Agricultura Brasileira, Vozes, Petrópolis, 118-126.

[27] de Moraes Dan, L.G., Dan, H.A., Braccini, A.L., Albrecht, L.P., Ricci, T.T. and Piccinin, G.G. (2011) Desempenho de sementes de soja tratadas com inseticidas e submetidas a diferentes períodos de armazenamento. Revista Brasileira de Ciências Agrárias, 6, 215-222. http://dx.doi.org/10.5039/agraria.v6i2a939

[28] Grisi, P.U., Santos, C.M., Fernandes, J.J. and Sá Júnior, A. (2009) Qualidade das sementes de girassol tratadas com inseticidas e fungicidas. Bioscience Journal, 25, 28-36.

[29] Vanin, A., Silva, A.G., Fernandes, C.P.C., Ferreira, W.S. and Rattes, J.F. (2011) Tratamento de sementes de sorgo com inseticidas. Revista Brasileira de Sementes, 33, 299-309. http://dx.doi.org/10.1590/S0101-31222011000200012

[30] Cataneo, A.C. (2008) Ação do Tiametoxam (Thiametoxam) sobre a germinação de sementes de soja (Glycine max L.): enzimas envolvidas na mobilização de reservas e na proteção contra situação de estresse (deficiência hídrica, salinidade e presença de alumínio). In: Gazzoni, D.L., Ed., Tiametoxam: Uma Revolução na Agricultura Brasileira. Vozes, Petrópolis, 127-192.

[31] Castro, P.R.C. (2006) Agroquímicos de controle hormonal na agricultura tropical. ESALQ, Piracicaba.

[32] Tavares, S., Castro, P.R.C., Ribeiro, R.V. and Aramaki, P.H. (2007) Avaliação dos efeitos fisiológicos de thiametoxan no tratamento de sementes de soja. Revista de Agricultura, 82, 47-54.

[33] Clavijo, J. (2008) Tiametoxam: um nuevo concepto em vigor y productividad. Ed. Arte Litográfico, Bogotá. 